\title{
Impact of the Effective Internal Control System on the Internal Audit Effectiveness at Local Government Level
}

\author{
Mu'azu Saidu Badara*, Siti Zabedah Saidin \\ Universiti Utara Malaysia, Malaysia \\ *muazubadara@yahoo.com
}

\begin{abstract}
Effective internal control system plays an important role in ensuring objective achievement of organizations. Therefore, the aim of this paper is to examine the relationship between effective internal control system and internal audit effectiveness at local government level. The paper is a literature review paper and the paper concluded that effective internal control system can influence the effectiveness of internal auditors at local level. The paper needs to be validated empirically.
\end{abstract}

Key Words: Effective internal control system, internal audit effectiveness, Local Government, component of internal control system

\section{Introduction}

As a result of the increase in accounting scandals in recent years, the internal audit function has received impressive attention as an important contributor to effective corporate governance and financial reporting, because a high quality internal audit function focused on improving financial reporting through ensuring standard compliance (Prawitt et al., 2008). However, control has been envisaged as the supervision over the execution of plans and taking necessary correction (Verdina, 2011). An internal control system issue has been found so significance to organization especially in the aspect of assurance of the reliability and accuracy of the financial reports, beside it is a subject that receives too little attention in the management literature (Changchit, Holsapple \& Madden, 2001). Therefore, there is need to conduct more research on the impact of effective internal control system as even recommend that more research in the area of internal control system effectiveness is required (Jokipii, 2010). Furthermore, the issue of effectiveness of internal audit is indispensable because it will create improvement in the government ministries (Unegbu \& Kida, 2011). In line with this, consideration over the measurement of the effectiveness of internal audit function keep receiving a significant challenges, consisting the finding of the best and relevant method for measuring the efficiency and effectiveness of internal audit (Bota \& Palfi, 2009; IIA, 2010; Spertus et al, 2010). In this vein, measurement of internal audit effectiveness should be considered because it has a role to play in achieving local objective. Therefore, Arena and Azzone (2010), Chaveerug (2011) and Mihret et al, (2010) emphasize the need for future studies to examine the factors that influence internal audit effectiveness and the possible interactions among them. Equally, it is interesting to focus on the model that will lead to the strength of internal audit effectiveness (Aguolu, 2009). In this vein, many studies that have been conducted on internal audit effectiveness give more concerned in companies' hotels, banks and few public sectors within the state level which their internal audit is a little big effective than those of local government. Similarly, Johnsen and Vakkuri (2001) noted that local government auditing has been less studied and reported in the literature. Therefore, this paper will examine the relationship between effective internal control system and internal audit effectiveness at local government level. Section two of the paper present the literature review, section three provide research framework and conclusion

\section{Literature Review}

Internal audit effectiveness: The word "effectiveness" have been defined by different researchers, for instance Arena and Azzone (2009) defined effectiveness "as the capacity to obtain results that are consistent with targets objective," while, Dittenhofer (2001) view effectiveness as the ability toward the achievement of the objectives and goals. In the same context, a program can be seen as effective if its outcome goes along with its objectives (Ahmad et al, 2009; Mihret et al, 2010). In this situation, internal audit effectiveness means the ability of the internal auditor to achieve the established objective within the local government. This goes along that the objectives of an internal audit for every organization are depending on the goals set out by the management of the organization (Pungas, 2003) as such, the objective of internal audit in local government should also goes a long with the set up goals by the 
management of the particular councils, even though the degree of internal audit effectiveness tends to vary within organizational level as well as country (Al-Twaijry et al., 2003). This mean the internal audit effectiveness can also vary within the local level. With regard to that, the internal audit should be able to achieve the established objective in order improve the performance of the organization. Consequently, to determine whether the internal auditing function is operating effectively or not, some things has to be consider which include; identification of the basic objective of internal auditing; define the goals to be accomplished by the internal auditing and establish measures that will assist toward the achievement of those goals (Aguolu, 2009; Dittenhofer, 2001) while Cassandra et at (2008) argued that in order to achieve internal audit objective, three basic conditions must be satisfy i.e. independence; organizational status; and objectivity, also (Feizizadeh, 2012) consideration was that, for an internal audit function to achieve high levels of effectiveness these four items must be consider; goes along with stakeholder needs; achieves best to his abilities; complies with relevant professional standards and; performance measures. Thus, Beckmerhagen et al (2004) also argued that the audit effectiveness should not be measured based on achievement of the audit objectives or on the number of findings of the internal auditor alone, but also more important is to determine the quality and suitability of the audit plan, execution and follow-up. Similarly, Shareholders should have the power to remove any internal auditor that is ineffective (Dhamankar \& Khandewale, 2003). This should also be in line with local council by removing all internal auditors that are not effective despite the provision of all necessary that might have improve their effectiveness.

Generally, researchers has also indicate some of the reasons behind the ineffectiveness of internal audit include; ineffective management controls, non clear definition of objectives by some organizations and inadequate support from top management (Ahmad et al, 2009; Dittenhofer 2001; Unegbu \& Kida, 2011). Therefore, in line with this, the implications of an ineffective internal audit in a public sector management can lead to; the possibility of the emergence of fraud; low or non compliance with internal policies and procedures; ineffective financial decision for successful operation (Unegbu \& Kida, 2011). Hence, the effective internal audits carry out an independent evaluation of the financial and operating information and systems and procedures with a view to provide good recommendations for improvements (Mihret \& Yismaw, 2007; New Delhi, 2006). That is why proper internal organization is also essential factor that lead to the achievement of internal audit effectiveness. Similarly, internal audit effectiveness can also be enhance by ensuring consistency in the documentation of audit work, quality of reporting and proper implementation of their recommendation (Mihret \& Yismaw, 2007). Therefore, having such effective internal audit within organization, will automatically helps to achieve performance and profitability and prevents in loss of revenues particularly in public sectors (Vijayakumar \& Nagaraja, 2012) even though Pilcher Gilchrist and Singh (2011) observed that efficiency and effectiveness of audit in a public sectors context is more complex than in the private sectors. But then consideration must be given to the effectiveness of internal auditors particularly at local level so as to improve their standard.

Several studies have been conducted on the internal audit effectivenessIn (Ahmad, Othman, and Jusoff, 2009; Arena \& Azzone 2009; Arena \& Azzone 2010; Boța \& Palfi 2009; Cohen \& Sayag, 2010; Dittenhoper, 2001; Feizizadeh, 2012; IIA, 2010; Mihret \& Yismaw, 2007; Mihret, James and Joseph, 2010; Theofanis, et al 2011; Ussahawanitchakit \& Intakhan, 2011). For example the study carried out by Ahmad et al (2009) on the effectiveness of internal audit in Malaysian public sector, using simple percentage for data analysis found the lack of audit staff is ranked as the major problem faced by internal auditors in conducting an effective internal auditing. The study concluded by suggesting that future studies should adopt other methods such as field survey of wider groups of internal auditors both in public and the private sectors. Likewise, Theofanis, et al (2011) examine the relationship between element of internal control system and internal audit effectiveness and the result of the study reveal positive relationship between the two relationships. Even though the studies used only 52 Hotels in Greek as a sample and mail survey for data collection, but at conclusion they suggest that if future studies should carried out research on internal audit effectiveness with large sample, the result will be better than their own. Also Feizizadeh (2012) carried out study on strengthening internal audit effectiveness and found that most of the companies measure and quantify the performance \& effectiveness of their business activities. Therefore, looking at the above studies, they consider the effectiveness of internal audit at company's level, hotels and banks ignoring such effectiveness at local level. In this vein, this study extends the previous study through examining such effectiveness at local government levels.

Effective internal control system: Glance (2006) provided that internal control system refers to "the local government process and procedure that is been established with the aim of objective achievement." 
Section 125 of (IAG, 2008) stipulated that "local government should provide a sound system of internal control system which should assist toward the achievement of objective." Similarly, the internal control system also serves as a process that guides an organization towards achieving its established objectives (Amudo \& Inanga, 2009; Baltaci \& Yilmaz, 2006; Jokipii 2010). From the above definition of internal control system, it can understand clearly that it all about the provision that will assist to the achievement of objectives. Therefore, for the purpose of this study effective internal control system refers to the effective control measures established by an organization with the aim of safeguarding their assets ensure the reliability of records both financial and non financial as well as compliance with relevant policies and procedure that will ensure the achievement of organizational objective. In this context, local government should ensure that their internal control system is well established in order to assist internal audit towards objective achievement of organization. Similarly, quality of an organization internal control system has significant impact on the accuracy of management guidance, likewise firms that disclose ineffective internal controls system have larger tendency of experiencing management errors in their operation than those firms that report effective internal controls system (Feng, Li \& McVay, 2009). Therefore, it is the responsibility of management of an organization to ensure that effective internal control system is put in place that will ensure the achievement of organizational established objectives. This is because establishment and supervision of effective internal control systems are the responsibility of management, not auditors (Changchit et al, 2001). At the same time effective internal controls system are fundamental drivers toward earnings quality (Church \& Schneider, 2008). In the same vein, effective internal control system has an essential role to play in a firm's success (Jokipii, 2010); in line with the above issue, effective internal control system could also play an important role in the effectiveness of internal auditors particularly at local government.

All of government ministries and agencies should improve the effectiveness of internal control system, internal audit function and organization commitment because they improve good governance (Eko \& Hariyanto, 2011) in addition, such effective internal control system can provide information to management about the entity's progress, or lack of progress toward the achievement of their objectives (Changchit et al, 2001; Jokipii, 2010; Nilniyom \& Chanthinok, 2011; Vijayakumar \& Nagaraja, 2012; Verdina, 2011). Therefore, Baltaci and Yilmaz (2006) observed that establishing internal control system and audit practices at the local government level has received little or no attention. And without establishing an effective internal control system at local government level, detection and control of misconduct in the local government would not be possible. Therefore, implementing and maintaining such effective internal control system will ensure compliance with laws and regulations even in health care section (Amudo \& Inanga, 2009; Gundling, 2000). Meanwhile, it is good for local government to improve the effectiveness of their internal control system in order to enhance the effectiveness of internal audit. Furthermore, the main responsibilities of internal control system in local government covers; ensuring full protection of council's assets; ensuring proper utilization of councils resources; proper authorization of revenue and expenditure; proper expenditure monitoring; removal of any misconduct in finances (Kwanbo, 2010). Due to the world recognition of the important of effective internal control system establishment at local level, some countries still have weak internal control system at their local level, for instance; Baltaci and Yilmaz (2006) discovered some of the world countries that has weak internal control system at their local government level which include; Argentina, Bosnia, China, Columbia, India-Karnataka State, Indonesia and Philippines. This is similar to the study of (Adeyime, 2012; Kuta, 2008; Kwambo 2009; Musa, 2012) which also found that local government in Nigeria has weak internal control system, which need to be improved. Also firms need to improve the effective and efficiency of their internal control system (Nilniyom \& Chanthinok, 2011). Similarly, Vijayakumar and Nagaraja (2012) show concerned that governing bodies of public sector entities need to ensure effective system of internal control because is one of the several factors that influence the performance of an organization and it plays a vital role in achieving management intended objectives that would lead to the successful operations. It is not enough for an organization to have internal controls system over their critical processes but is to ensure that those controls are effective (Candreva, 2006).

Al-Twaijry et al (2004) also found that effectiveness of internal control system helps external auditors to rely on the work of internal auditors and thereby improve their effectiveness. Therefore, internal control systems are integral component of the management processes of a public sector which should be establish in order to provide reasonable assurance that the operations are carried out efficiently and effectively. Effective internal controls systems are essential to the effectiveness of local governments operation because it deals with the activities or procedures that are designed to provide reasonable assurance that operations are performing according to plan and these can also influence the effectiveness 
of internal audit. COSO also provides the basic principles representing the fundamental concepts of effective internal control in five components of the framework (Candreva, 2006; Sudsomboon \& Ussahawanitchakit, 2009). Though Amudo and Inanga (2009) argued that the weakness of the COSO mechanism is failure to recognize Information Technology as one of the major control components of internal control system and Information Technology is very crucial to internal control framework. That is why most organizations today used Information Technology for authorization, initiation, recording and processing of transactions, because its ensures effectiveness of internal controls system and thereby making it six. At the same time advancements in technological have increased the importance placed on internal controls system (Rezaee et al, 2001). These components must be present and functioning effectively for any internal control system to achieve organizational objectives (COSO):

- Control environment: Is the major aspect of managing an organization this is because is a reflection of the attitude and the policies of management in regard with the importance of internal audit in the economic unit (Theofanis, et al 2011). It has influence over organization goals achievement (Aldridge \& Colbert, 1994). However, it is the foundation for the other components of internal control and providing structure (Sudsomboon \& Ussahawanitchakit, 2009). Control environment assist toward reducing the level fraudulent activities within organizational operation also the quality of an entity's internal controls system depend on the function and quality of their control environment (Amudo \& Inanga, 2009). Therefore, providing a proper control environment for a local government is very essential to the effectiveness of their operation.

- Risk assessment: This is the identification and analysis of relevant risks associated with the achievement of the management objectives (Theofanis, et al 2011), similary (Sudsomboon \& Ussahawanitchakit, 2009) view risk assessment as the process of identifying and analyzing management relevant risks to the preparation of financial statements that would be presented fairly in conformity with general accepted accounting principle. In this situation, management must determine the level of risk carefully to be accepted, and should try to maintain such risk within determined levels. Therefore, local governments are required to frequently assess the level of risk their experiencing in order to take necessary actions.

- Control activities: These are policies, procedures and mechanisms that ensure management's directives are properly carry out (Aikins, 2011; Rezaee, Elam \& Sharbatoghlie, 2001). Proper documentation of policies and procedural guidelines in these aspects help to determine not only how the control activities are to be executed but also provide adequate information for auditors examination of the overall adequacy of control design over financial management practices (Aikins, 2011). This control activities ensure that all necessary actions should be taken with the aim to address risks so that organizational objectives are achieves. Example of control activities include; segregation of duties, daily deposit of cash receipts, bank reconciliations and limiting access to check stock

- Information and communication: refers to the process of identifying, capturing, and communicating of relevant information in an appropriate manner and within timeframe in order to accomplish the financial reporting objectives (Aldridre \& Colbert, 1994). However, effective communications should occur in a wider sense with information within the various sections of the organization (Theofanis et al, 2011). Most of the recent literature on internal control system frameworks gave concerned on information and communication as one of the internal control system components, because of their importance in influencing the working relationship within the organization at all levels (Amudo \& Inanga, 2009). Hence, such information must be communicated throughout the entire organization in order to permit personnel to carry out their responsibilities with regard to objective achievement.

- Monitoring: it is usually accepted that internal control systems need to be adequate monitored in order to assess the quality and the effectiveness of the system's performance over time. Monitoring provides assurance that the findings of audits and other reviews are promptly determined (Theofanis et al, 2011), also monitoring of operations ensures effective functioning of internal controls system (Amudo \& Inanga, 2009). Hence, monitoring determines whether or not policies and procedures designed and implemented by management are being carried out effectively by employees.

Several studies have been conducted research on internal control system but none of them study the impact of effective internal control system on internal audit effectiveness, particularly at local government level (Aikins 2011; Baltaci \& Yilmaz, 2006; Eko \& Hariyanto, 2011; Feng et al, 2009; Kwanbo, 2009; Nilniyom \& Chanthinok, 2011) for instance a study carried out by Eko and Hariyanto (2011) on the relationship between internal control system, internal audit, and organization commitment with good 
governance: Indonesian Case. The study consider local government of Central Java province, Indonesia, consist of 35 districts with questionnaires and found that internal control system, internal audit, and organization commitment have positive significant relationship with the good governance. Also the study carried out by Baltaci and Yilmaz (2006) on keeping an eye on sub national governments: Internal control and audit at local levels. Though the study is conceptual and found that internal control system and audit are the key components of public financial management systems for increasing efficiency and effectiveness in local government operations. In a related study carried out by Nilniyom and Chanthinok (2011) on accounting system innovation and stakeholder acceptance of Thai listed firms: Mediating internal control effectiveness used mailed survey and questionnaires for methodology. The result of the study reveals that internal control effectiveness has a positive relationship with stakeholder acceptance. Feng et al (2009) also carried out a study on internal control and management guidance, used questionnaire and finally found that internal control quality has an economically significant effect on the accuracy of management guidance. Similarly, Aikins (2011) under take a research on an examination of government internal audits' role in improving financial performance, in which he used the local government financial performance as dependent variable and independent variables of; the effects of years between audits, internal control adequacy, internal control system effectiveness, and evaluation of financial performance monitoring, used online survey, 387 audit department head and questionnaire for methodology. The research results indicate significant relationships between years between audits, internal control adequacy, internal control effectiveness and evaluation of financial performance monitoring on local government financial performance. However, looking at the above studies that has been conducted on effective internal control system, none of the above studies examined the relationship between effective internal control system with internal audit effectiveness particularly at local government level, therefore this research extend the previous research through examining the relationship between effective internal control system and internal audit effectiveness at local government level.

\section{Theoretical framework}

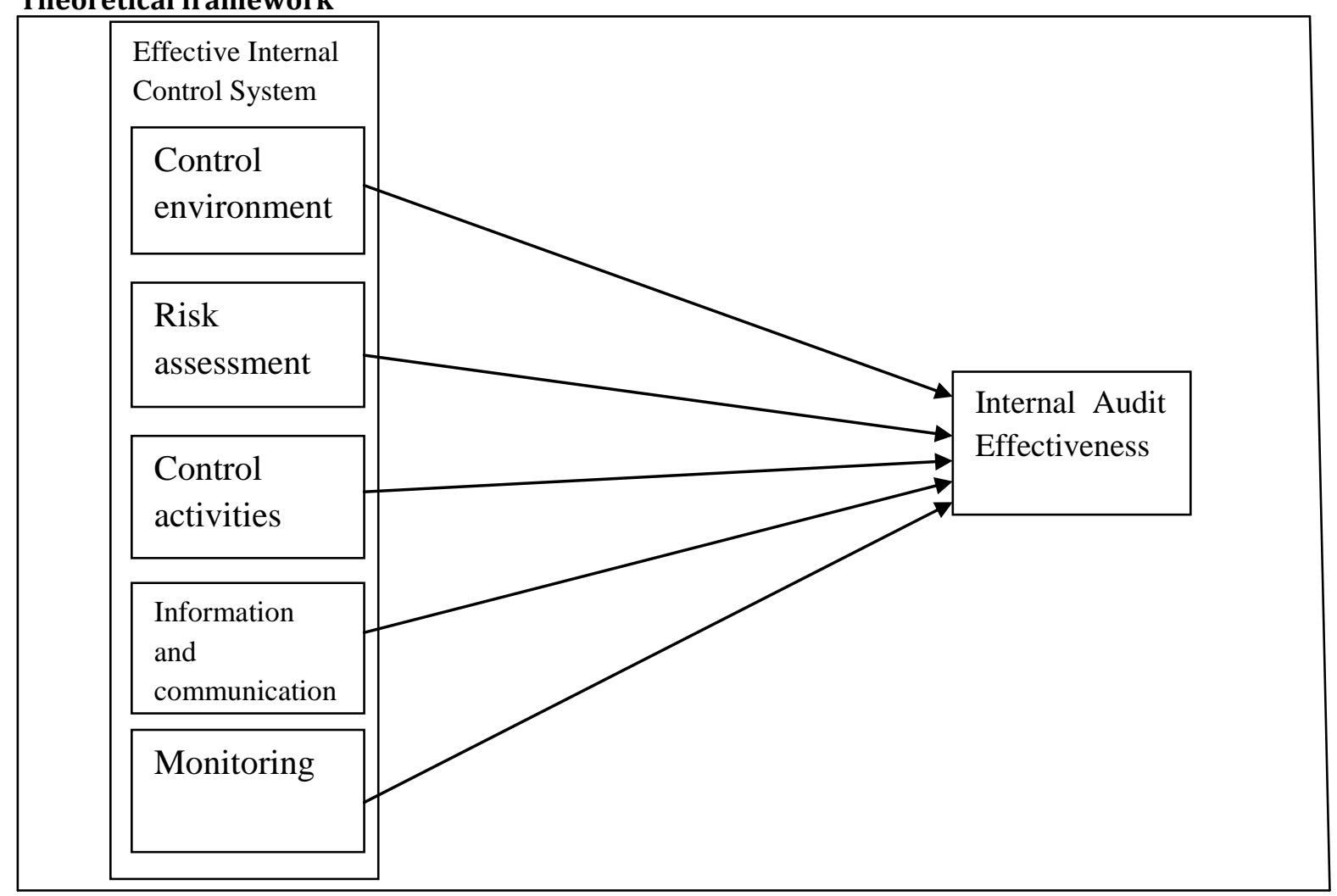

\section{Proposition}

- P1 Control environment relate to the effectiveness of internal audit at local government level.

- P2 Risk assessment has impact on internal audit effectiveness at local government level.

- P3 Control activities influence the effectiveness of internal audit at local government level.

- P4 Proper information and communication enhance the effectiveness of internal audit at local level. 
- P5 Proper monitoring is related to the effectiveness of internal audit effectiveness at local government level.

Underpinning Theory: Contingency theory is not a new theory in an organizational research because it has a well established concepts in organizational literature (Donaldson, 2001; Sauser, Reilly \& Shenhar, 2009) mean while, for the past three decades, contingency theory has been the subject of wider research area but yet it is still developing (Ayman, Chemers \& Fiedler, 1995), even though the early researchers on contingency theory in organization design mainly focuses on the effects of uncertainty on the organizational structure (Chenhall, 2003; Drazin \& Van de Ven, 1985; Reid \& Smith, 2000). However, contingency theory is known as one of those theory that are usually been used recently in management accounting and auditing research (Abushaiba \& Zainuddin, 2012; Reid \& Smith, 2000; Sudsomboon \& Ussahawanitchakit, 2009; Valanciene \& Gimzauskiene, 2009) though the utilization of the theory may have different effect, and equally it effectiveness depend upon the stage/or field that is been proposed (Chenhall, 2003; Drazin \& Van de Ven, 1985) additionally, the relevant of any given factor should be contingent upon other factors (Krishnamoorthy, 2002) but then contingency theory enables a researcher to systematically introduce factors to explain or predict expected phenomena (Umanath, 2003). This is because it does depend on one's interpretation of the theory, and such theory has the capability of producing accurate hypotheses and consistent functions (Schoonhoven, 1981). Therefore, indicate the possibility of applying contingency framework in the public sectors (Wood, 2009). Mean while a contingency theory also differs with other theories in the form of their specific propositions, this is because it's hypothesize a conditional relationship between two or more independent variables with a dependent variable and subject it to an empirical test (Drazin \& Van de Ven, 1985). Therefore, this study proposes that internal audit effectiveness at local government level is contingent upon those components of effective internal control system.

\section{Conclusion}

This paper presents the relationship between the effective internal control system and internal audit effectiveness at local level. The paper is constraint to only considering the effective internal control system; it is a conceptual literature review paper at local government level. However, despite the limitation of the paper, the paper contribute to knowledge by extending the existing literature on the internal audit effectiveness through determining the effectiveness of internal audit at local level through effective internal control system, the paper also contribute on the internal audit effectiveness at local level since most of the previous studies fail to develop a model showing the relation between effective internal control system and internal audit effectiveness at local level. Despite the fact that this paper is part of ongoing PhD thesis of the researcher. Future research should validate it in other countries using different kind of analysis. Likewise future research should look at the possibility of inserting other moderating or mediating variables to strength or to influence the relationship between effective internal control system and internal audit effectiveness.

\section{References}

Abushaiba, I. A. \& Zainuddin, Y. (2012). Performance measurement system design, competitive capability, and performance consequences-A conceptual like. International Journal of Business and Social Science, 3(11), 184-193.

Adeyemi, O. O., Akindele, S. T. \& Agesin, B. (2012). Review: Institutionalizing the culture of accountability in local government administration in Nigeria. African Journal of Political Science and International Relations, 6(4), 81-91.

Aguolu, 0. (2009). Designing an effective internal audit group. Association of Accountancy Bodies in West Africa, 1(4), 60-76.

Ahmad, N., Othman, R. \& Jusoff, K. (2009). The effectiveness of internal audit in Malaysian public sector. Journal of Modern Accounting and Auditing, 5(9), 784-790.

Aikins, S. K. (2011). An examination of government internal audits' role in improving financial performance. Public Finance and Management, 11(4), 306-337.

Aldridge, R. \& Colbert, J. (1994). Management's report on internal control, and the Accountant's response. Managerial Auditing Journal, 9(7), 21-28.

Al-Twaijry, A. A. M., Brierley, J. A. \& Gwilliam, D. R. (2003). The development of internal audit in Saudi Arabia: An Institutional Theory perspective. Critical Perspective on Accounting, 14, 507-531. 
Al-Twaijry, A. A. M., Brierley, J. A. \& Gwilliam, D. R. (2004). An examination of the relationship between internal and external audit in the Saudi Arabian corporate sector. Managerial Auditing Journal, 19(7), $929-944$.

Amudo, A. \& Inanga, E. L. (2009). Evaluation of internal control systems: A case study from Uganda. International Research Journal of Finance and Economics, 3, 124 -144.

Arena, M. \& Azzone, G. (2009). Identifying organizational drivers of internal audit effectiveness. International Journal of Auditing, 13, 43-60.

Arena, M. \& Azzone. G. (2010). Internal audit effectiveness: Relevant drivers of auditee's satisfaction1-35.

Ayman, R., Chemers, M. M. \& Fiedler, F. (1995). The contingency model of leadership effectiveness: Its levels of analysis. Leadership Quarterly, 6(2), 147-167.

Baltaci, M. \& Yilmaz, S. (2006). Keeping an eye on Subnational Governments: Internal control and audit at local levels. World Bank Institute Washington, D.

Beckmerhagen, I. A., Berg, H. P., Karapetrovic, A. \& Willborn, W. O. (2004). On the effectiveness of quality management system audits. The TQM Magazine, 16(1), $14-25$.

Bota, C. \& Palfi, C. (2009). Measuring and assessment of internal audit's effectiveness. Economic Science Series, 18(3), 784-790.

Candreva, P. J. (2006). Controlling internal controls. Public Administration Review, 66(3), 463-465.

Cassandra, S. L., Yee, A. S., Kieran, J. \& Jenny, K. S. (2008). Perceptions of Singaporean internal audit customers regarding the role and effectiveness of internal audit. Asian Journal of Business and Accounting, 1(2), 147-174.

Cohen, A. \& Sayag, G. (2010). The Effectiveness of internal auditing: An empirical examination of its determinants in Israeli organizations. Australian Accounting Review, 54 (20), 296-307.

Changchit, C., Holsapple, C. W. \& Madden, D. L. (2001). Supporting managers' internal control evaluations: An expert system and experimental results. Decision Support Systems, 30, 437-449.

Chaveerug, A. (2011). The role of accounting information system knowledge on audit effectiveness of CPAS in Thailand. International journal of business strategy, 11, 78 - 89.

Chenhall, R. H. (2003). Management control systems design within its organizational context: Findings from contingency-based research and directions for the future. Accounting Organizations and Society, 28, 127-168.

Church, B. K. \& Schneider, A. (2008).The effect of auditors' internal control opinions on loan decisions. Journal of Accounting and Public Policy, 27, 1-18.

Dittenhofer, M. (2001). Internal auditing effectiveness: An expansion of present methods. Managerial Auditing Journal, 16(8), 443 - 450.

Donaldson, L. (2001). The contingency theory of organizations. Thousand Oaks, CA: Sage Publications London.

Dhamankar, R. \& Khandewale, A. (2003). Effectiveness of Internal Audits. The Chartered Accountant, 2, $275-279$.

Drazin, R. \& Van de Ven, A. H. (1985). Alternative forms of fit in contingency Theory. Administrative Science Quarterly, 30, 514-539.

Eko, S. \& Hariyanto, E. (2011) Relationship between internal control, internal audit, and organization commitment with good governance: Indonesian Case.

Feizizadeh, A. (2012). Strengthening internal audit effectiveness. Indian Journal of Science

and Technology, 5(5), 2777- 2778.

Feng, M., Li, C. \& McVay, S. (2009). Internal control and management guidance. Journal of Accounting and Economics, 48, 190-209

Gundling, R. L. (2000). Effective internal control systems are keys to ensuring compliance. Journal of Health Care Compliance, 1, 1-10.

Glance, A. (2006). Effectiveness of internal control. Local Government: Results of the 2006- 07 Audits, 19 $-26$.

IAG. (2008). Internal Audit Guidelines Department of Local Government Alternative Media Publications.

Johnsen, A. \& Vakkuri, J. (2001). Performance auditing in local government: an exploratory study of perceived efficiency of municipal value for money auditing in Finland and Norway. The European Accounting Review, 10(3), 583-599.

Jokipii, A. (2010). Determinants and consequences of internal control in firms: a contingency theory based analysis. J Manag Gov, 14, 115-144.

Kuta, H. I. (2008). Effectiveness of auditing for proper accountability in Nigerian local governments. Social Science Research $\quad$ Network. Available online at http://papers.ssrn.com/sol3/cf_dev/AbsByAuth.cfm?per_id=1594999\#show1955528 
Krishnamoorthy, G. (2002). A multistage approach to external auditor's evaluation of the internal audit function. Auditing: A journal of practice and theory, 21(1), $95-122$.

Kwanbo, M. L. (2009). Internal Control System and the issues of independence and confidentiality in local governments Auditing: An examination. Electronic copy available at: http://ssrn.com/abstract=1366664.

Mihret, D. G. \& Yismaw, A. W. (2007). Internal audit effectiveness: An Ethiopian public sector case study. Managerial Auditing Journal, 22(5), 470-484.

Mihret, D. G., James, K. \& Joseph, M. M. (2010). Antecedents and organizational performance implications of internal audit effectiveness: some propositions and research agenda. Pacific Accounting Review, 22(3), 224 - 252.

Mizrahi, S. \& Ness-Weisman, I. (2007). Evaluating the effectiveness of auditing in local municipalities using analytic hierarchy process (ahp): A general model and the Israeli example. International Journal of Auditing, 11, 187-210.

Musa, A. (2012). Transforming local governments into viable, democratic third tier. Daily Triumph. Retrieved on $\quad 10 / 06 / 2012$ from file://C:/Users/student/Downloads/Triumph\%20Newspapers\%20\%20Transforming\%20local \%20governments\%20into\%20viable,\%20democraticR\%20third\%20tier.htm.

New Delhi. (2006). Seminar on improving the effectiveness of internal audit in government of India. 1-38.

Nilniyom, P. \& Chanthinok, K. (2011). Accounting system innovation and stakeholder acceptance of Thai listed firms: Mediating internal control effectiveness. Review of Business Research, 11, 26 - 37.

Pilcher, R., Gilchrist, D. \& Singh, I. (2011). The Relationship between internal and external audit in the public sector - A Case Study.1-23.

Pungas, K. (2003). Risk assessment as part of internal auditing in the government institutions of the Estonian Republic. EBS Review summer, 3, 42-46.

Prawitt, D. F., Smith, J. L. \& Wood. D. A (2008). Internal audit quality and earnings management. Institute of Internal Auditors Research Foundation, 1-42. Electronic copy available at: http://ssrn.com/abstract=916081

Reid, G. C. \& Smith, J. A. (2000). The impact of contingencies on management accounting system development. Management Accounting Research, 11, 427- 450.

Rezaee, Z., Elam, R. \& Sharbatoghlie, A. (2001). Continuous auditing: The audit of the future. Managerial Auditing Journal, 16(3), 150-158.

Sauser, B. J., Reilly, R . R. \& Shenhar, A. J. (2009). Why projects fail? How contingency theory can provide new insights - A comparative analysis of NASA's Mars Climate Orbiter loss. International Journal of Project Management, 27, 665-679.

Sudsomboon, S. \& Ussahawanitchakit, P. (2009). Professional audit competencies: the effects On Thai's CPAS audit quality, reputation, and success. Review of Business Research, 9(3), 66 - 85.

Schoonhoven, C. B. (1981). Problems with contingency theory: Testing assumptions hidden within the Language of Contingency Theory. Administrative Science Quarterly, 26, 351-377.

Spertus, J. A., Eagle, K. A., Krumholz, H. M., Mitchell, K. R. \& Normand, S. L. (2010). American College of Cardiology American Heart Association New Insights into the Methodology of Performance Measurement. Journal of the American College of Cardiology, 56(21), 1768- 1780.

Theofanis, K., Drogalas, G. \& Giovanis, N. (2011). Evaluation of the effectiveness of internal audit in Greek Hotel Business. International Journal of Economic Sciences and Applied Research, 4(1), 19-34.

Umanath, N. S. (2003). The concept of contingency beyond It depends illustrations from IS research stream. Information \& Management, 40, 551-562.

Unegbu, A. O. \& Kida, M. I. (2011). Effectiveness of internal audit as instrument of improving public Sector management. Journal of Emerging Trends in Economics and Management Sciences (JETEMS), 2(4), 304-309.

Ussahawanitchakit, A. \& Intakhan, A. (2011). Audit professionalism, audit independence and audit effectiveness of CPAs in Thailand. International Journal of Business Research, 11(2), 1-11.

Valanciene, L. \& Gimzauskiene, E. (2009). Dimensions of performance measurement system in changes research. Engineering Economics, 4, 41-48.

Verdina, G. (2011). Risk management as a tool for securing internal control in the process of study program implementation at higher education institutions. Economics and management, 16, 987991.

Vijayakumar, A. N. \& Nagaraja, N. (2012). Internal control systems: Effectiveness of internal audit in risk management at public sector enterprises. BVIMR Management Edge, 5(1), 1-8.

Woods, M. (2009). A contingency theory perspective on the risk management control system within Birmingham City Council. Management Accounting Research, 20, 69-81. 